\title{
A Review of Colitis Ulcers in the Gastrointestinal Tract
}

Shiva Hadi*, Mahtab Farrash Bashi Masjed, Naser Shagerdi Esmaeli, Shahin Asadi

Department of Laboratory Hematology and Blood Bank, Shahid Behesht University of Medical Science, Tehran, Iran.

*Corresponding Author: Shahin Asadi, Medical Genetics-Harvard University. Director of the Division of Medical Genetics and Molecular Optogenetic Research \& Massachusetts Institute of Technology (MIT)

Received date: September 25, 2021; Accepted date: September 28, 2021; Published date: January 06, 2022

Citation: Hadi s., Mahtab F.M. Masjed, Naser S. Esmaeli, Asadi S. (2022) A Review of Colitis Ulcers in the Gastrointestinal Tract; J. Gastroenterology Pancreatology and Hepatobilary Disorders, 6(1) DOI: 10.31579/2641-5194/051

Copyright: (C) 2022, Shahin Asadi, This is an open access article distributed under the Creative Commons Attribution License, which permits unrestricted use, distribution, and reproduction in any medium, provided the original work is properly cited.

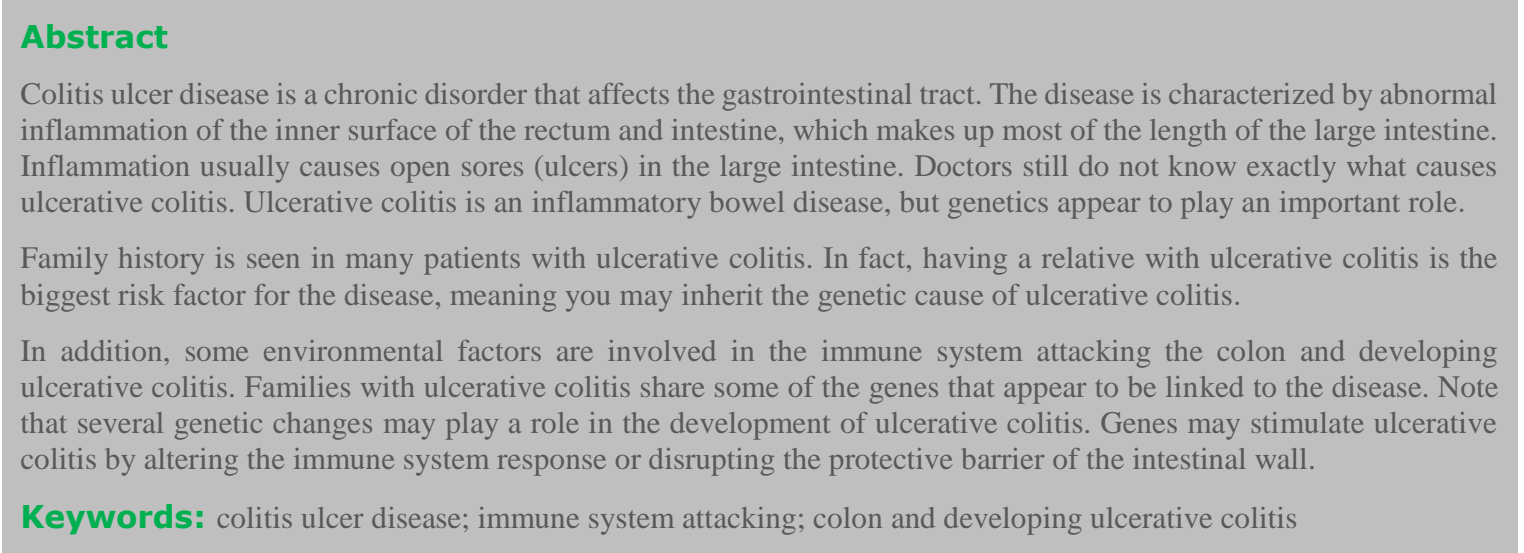

\section{Generalities of Colitis Ulcer Disease}

Colitis ulcer disease is a chronic disorder that affects the gastrointestinal tract. The disease is characterized by abnormal inflammation of the inner surface of the rectum and intestine, which makes up most of the length of the large intestine. Inflammation usually causes open sores (ulcers) in the large intestine. Colitis ulcers usually appear between the ages of 15 and
30, although they can occur at any age. This inflammation tends to get worse several times in a lifetime, causing recurrence of its symptoms [1].

Herpes simplex virus (HSV) is a pathogenic virus that can rarely infect the gastrointestinal tract, especially in people with a history of internal or external immunosuppression [1]. 


\section{TYPES OF ULCERATIVE COLITIS}

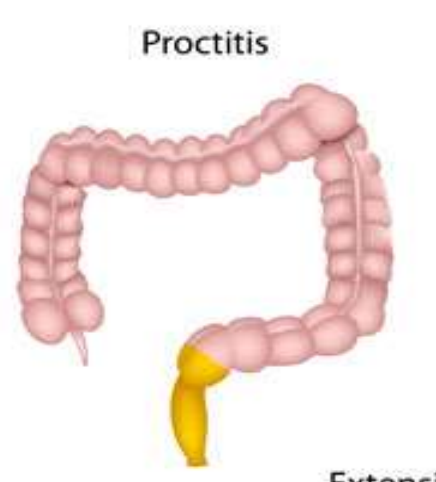

\section{Proctosigmoiditis}

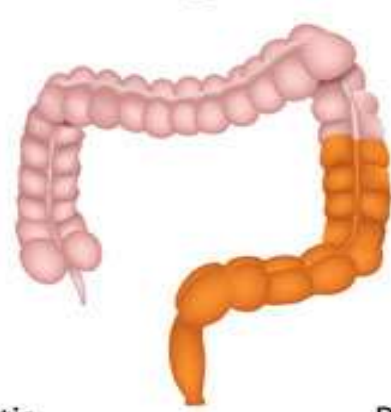

\section{Distal colitis}

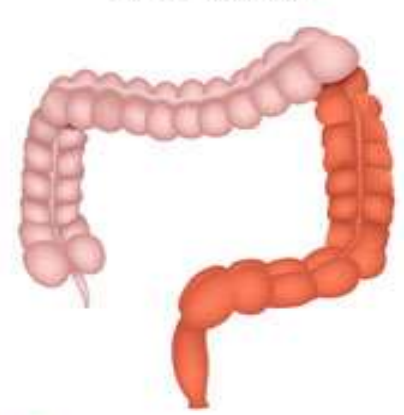

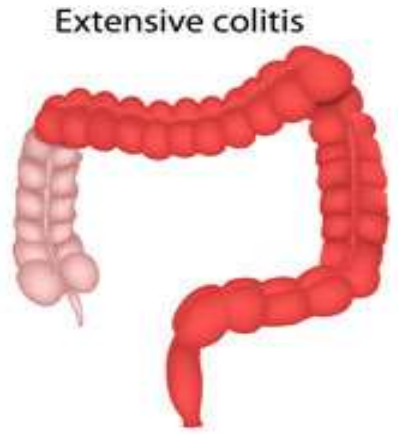

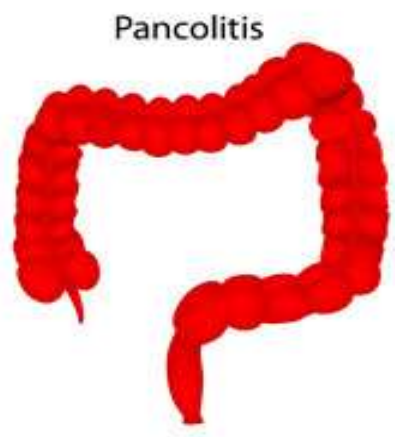

Figure 1: Schematic of different types of colitis ulcers [1].

\section{Clinical Signs and Symptoms of Colitis Ulcer Disease}

The most common symptoms of colitis ulcers are abdominal pain and cramping and recurrent diarrhea, often with blood, pus, or mucus in the stool. Other signs and symptoms include nausea, loss of appetite, fatigue and fever. Chronic bleeding from inflamed intestinal tissue and ulcers can cause red blood cell deficiency (anemia) in some people. People with this disorder have difficulty absorbing enough fluids and nutrients from their diet and often lose weight. Affected children usually grow slower than normal. Typically, colitis ulcers cause problems with the skin, joints, eyes, kidneys, or liver, most likely due to abnormal inflammation [2].

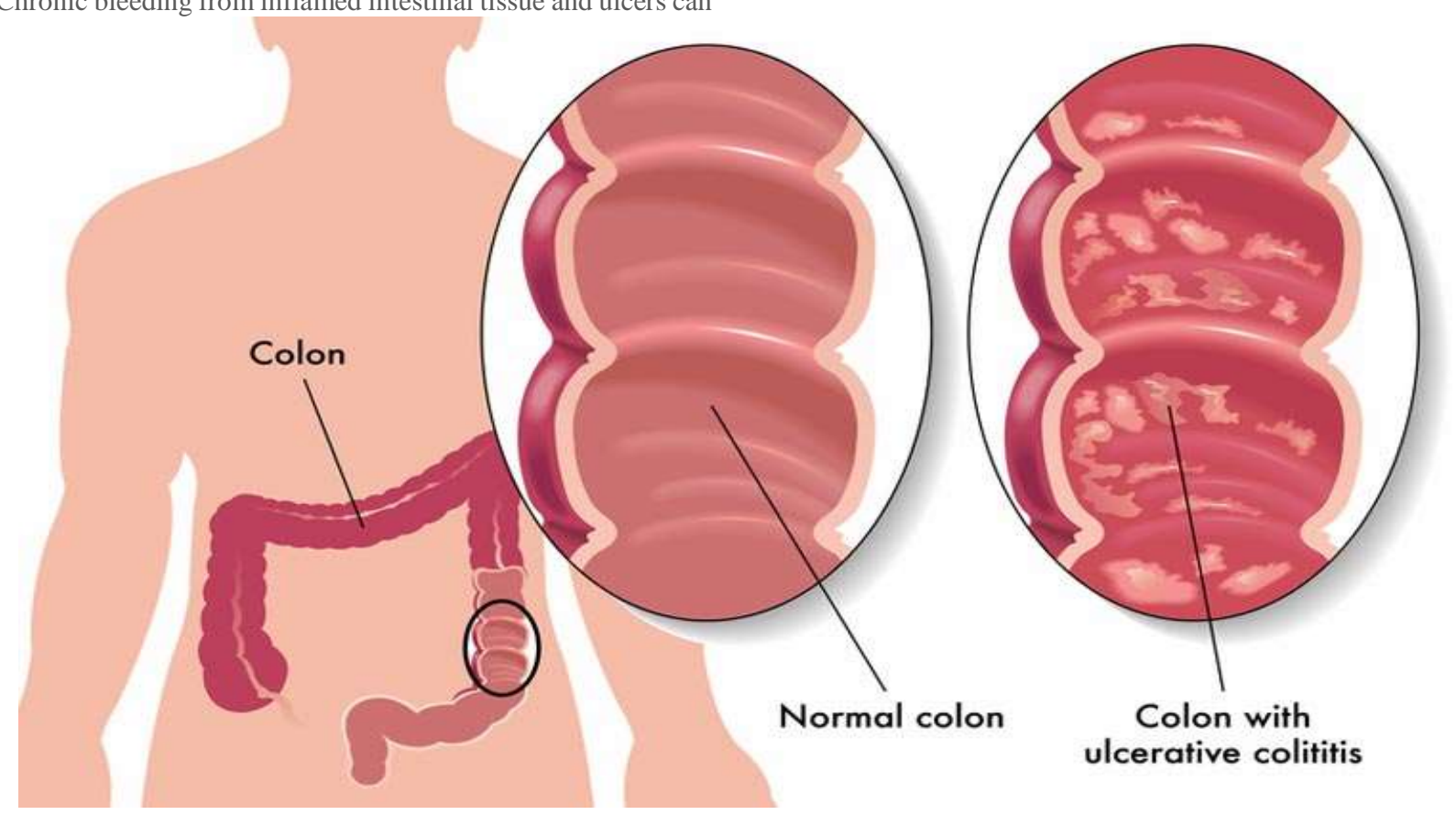

Figure 2: Schematic of a normal colon versus a colon with a colitis ulcer [1]. 
Toxic megacolon is a rare complication of colitis ulcer that can be life threatening. Toxic megacolon includes dilatation of the large intestine and excessive bacterial infection (sepsis). Colitis ulcers also increase the risk of colon cancer, especially in people whose entire colon is inflamed and in people who have had colitis ulcers for 8 years or more [2].

\section{COLITIS}
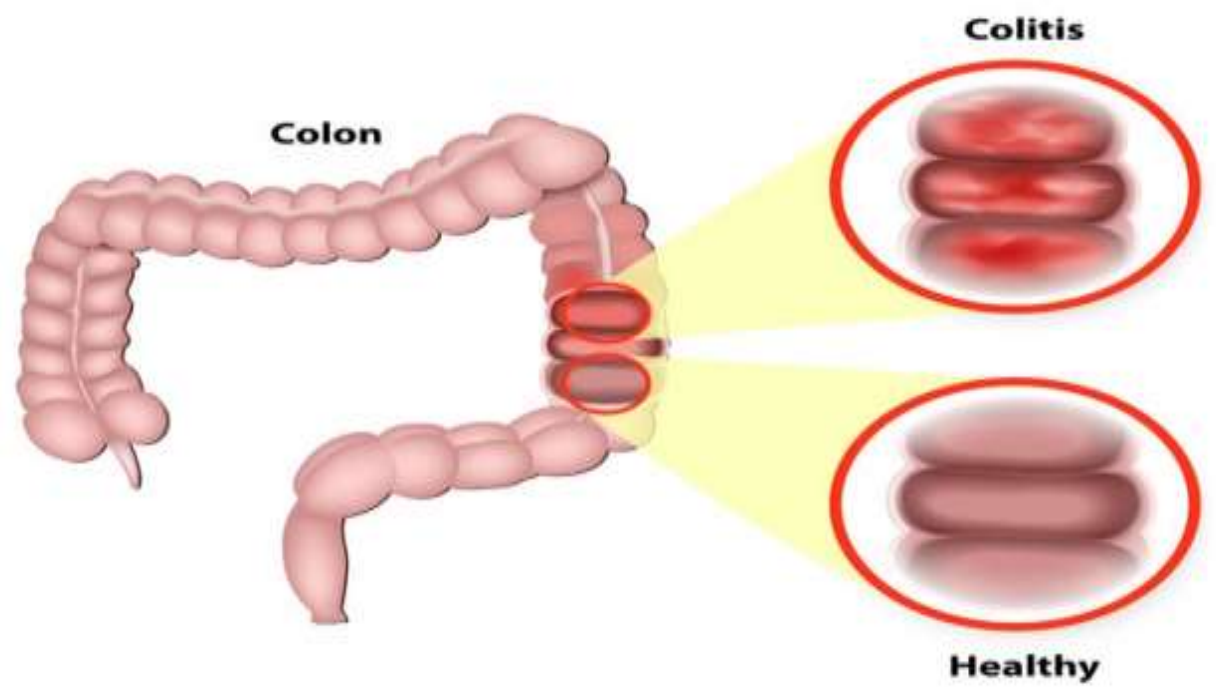

Figure 3: Schematic of a healthy colon versus colitis ulcer in the colon [2].

Colitis ulcer is a common type of inflammatory bowel disease (IBD). Another type of IBD is Crohn's disease, which causes chronic inflammation of the intestines. Unlike colitis ulcers, which affect only the inner surface of the large intestine, Crohn's disease can cause inflammation in any part of the gastrointestinal tract, and the inflammation can spread deeper into the intestinal tissue [3].

Etiology of Colitis Ulcer Disease
A variety of genetic and environmental factors are involved in the development of colitis ulcers. Recent studies have identified changes in dozens of genes that may be associated with colitis ulcers. However, the role of these changes is not fully understood. Researchers speculate that this condition may be due to changes in the protective function of the lining of the gut or an abnormal immune response to normal bacteria (normal flora) in the gastrointestinal tract, both of which may be due to genetic changes [3].

\section{Inflammatory Bowel Disease}

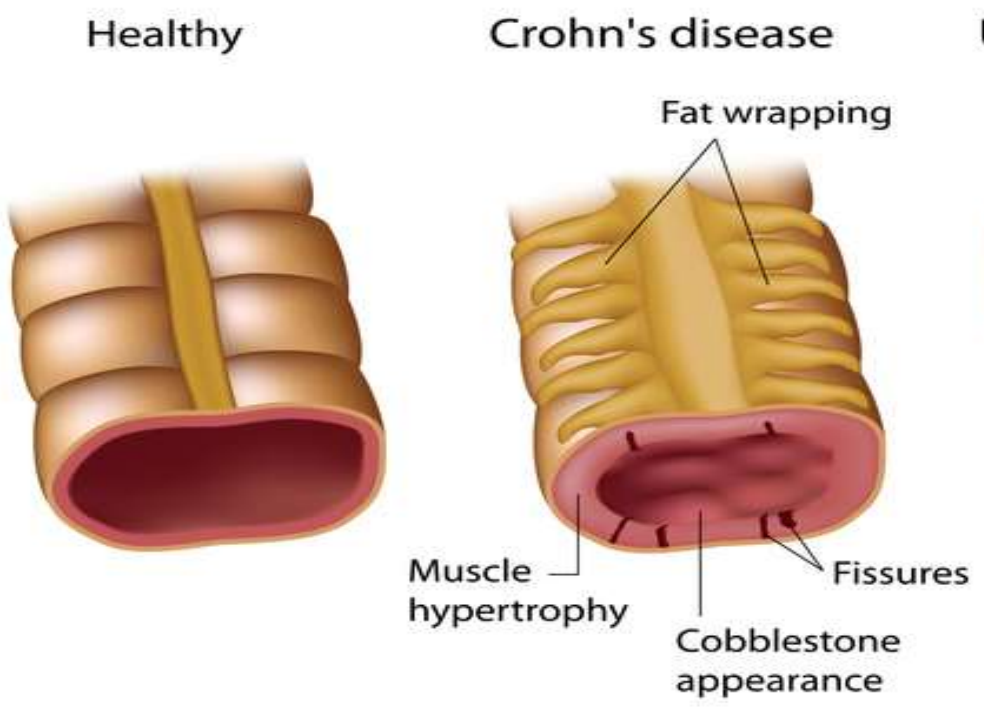

\section{Ulcerative colitis}

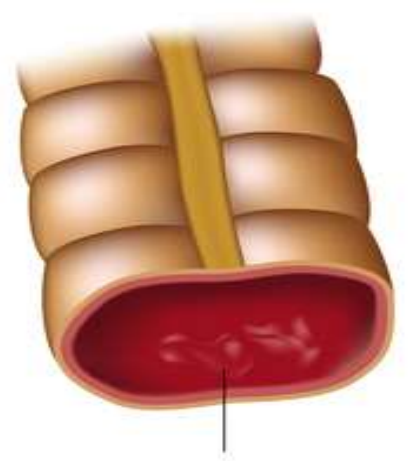

Ulceration within
the mucosa

Figure 4: Schematic of a healthy colon (left), a colon with Crohn's disease (middle) and a colon with a colitis ulcer (right) in inflammatory bowel disease (IBD) [3]. 
Several genes that may be associated with colitis ulcers are involved in the protective function of the intestines. The inner surface of the intestines provides a barrier that protects body tissues from bacteria that live in the intestines and toxins that pass through the gastrointestinal tract. Researchers speculate that breaking down the barrier could allow contact between intestinal tissue and bacteria and toxins, which could be an immune response. This immune response may lead to chronic inflammation and gastrointestinal problems characteristic of colitis ulcers [4].

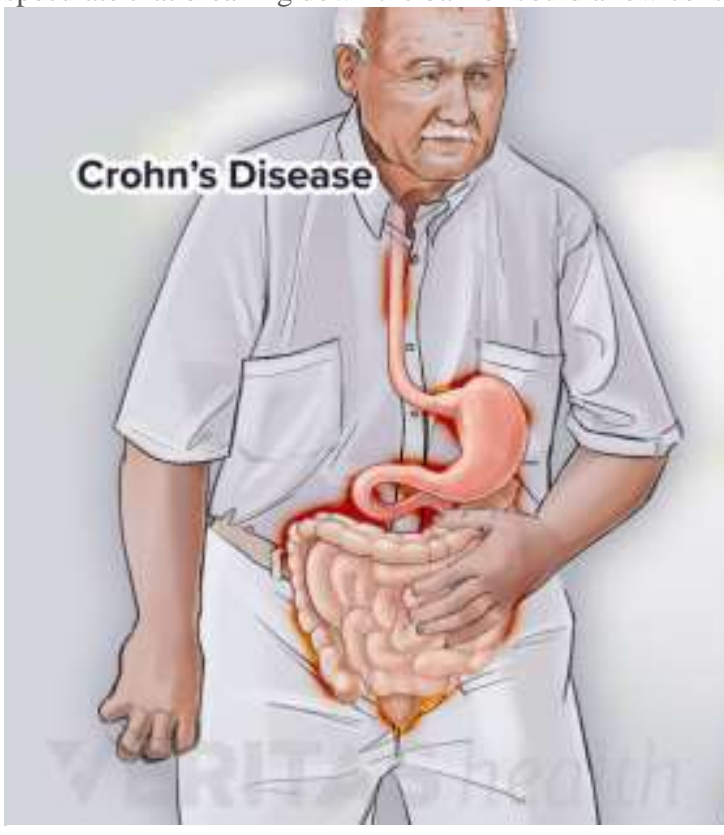

\section{Ulcerative Colitis}

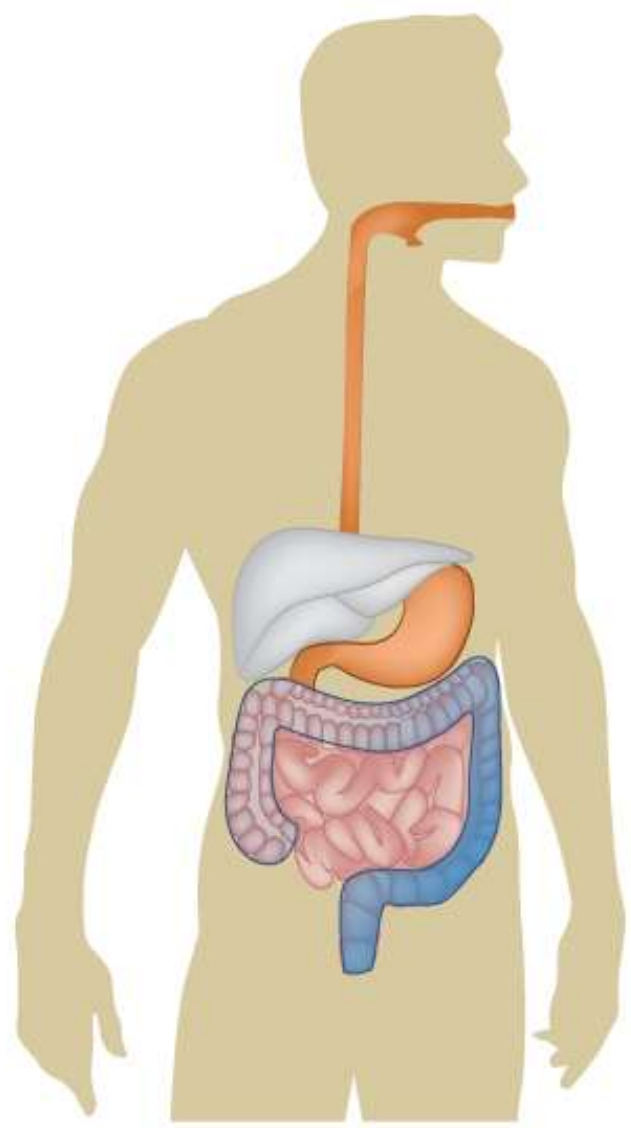

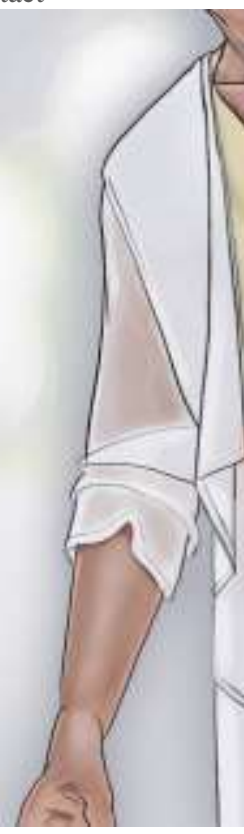

Crohn's Disease

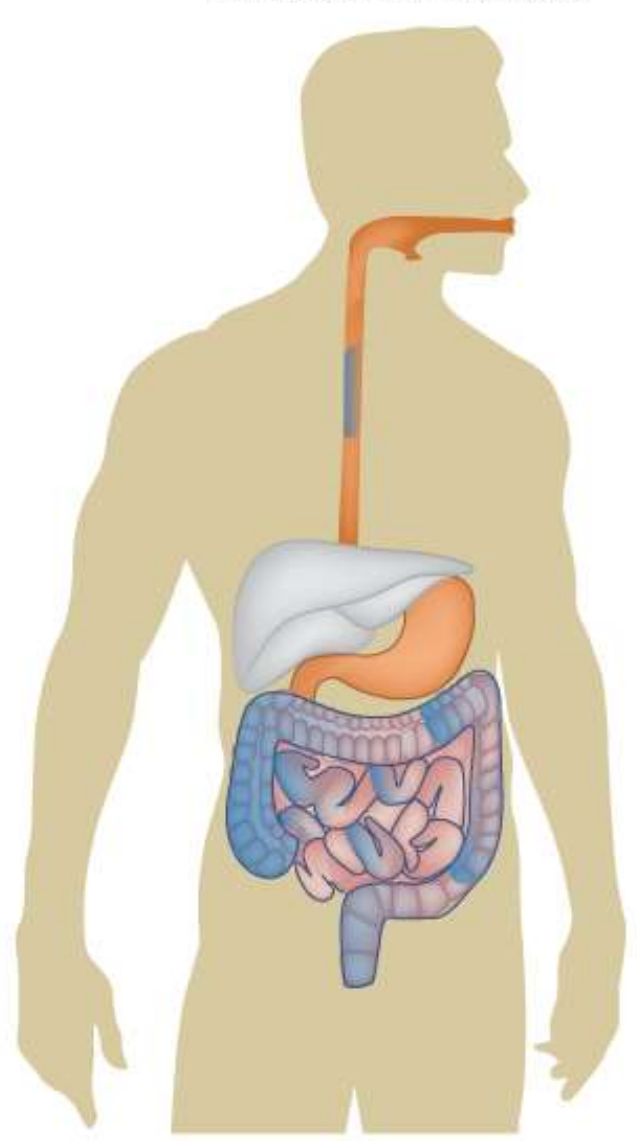

Figure 5: Schematic of inflammation in Crohn's disease and colitis ulcer [4]. 
Other genes associated with the disease are involved in the immune system, especially in the maturation and function of immune cells called $\mathrm{T}$ cells. $\mathrm{T}$ cells detect foreign substances and protect the body against infection. Some genetic changes may expose some people to an overactive immune response against bacteria and other gut microbes, which can lead to chronic inflammation that develops in colitis ulcers. Another possible explanation is that colitis ulcers occur when the immune system is defective and attacks intestinal cells, causing inflammation [4].

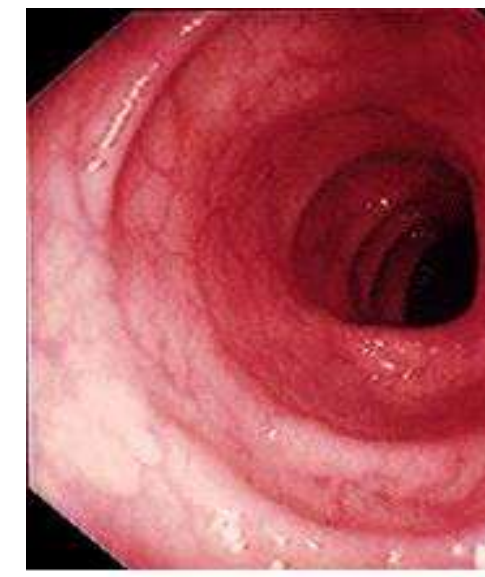

Healthy Colon

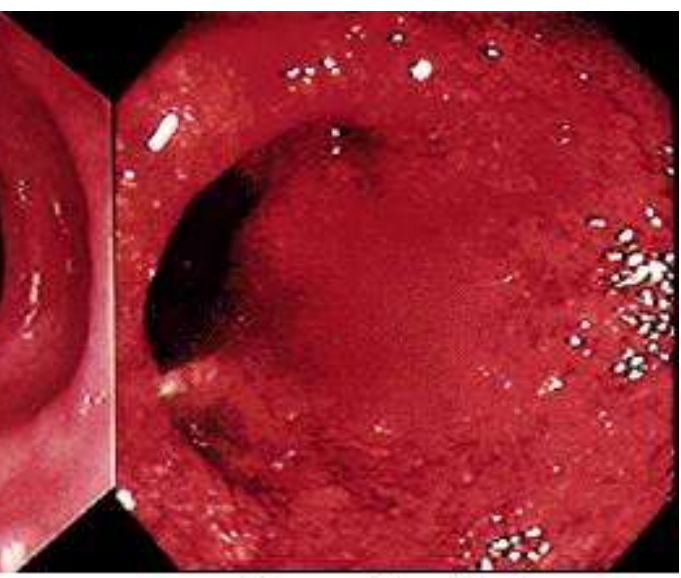

Ulcerative Colon

Figure 6: Endoscopic image of a healthy colon versus a colitis ulcer [4].

The hereditary pattern of colitis ulcers is unknown because many genetic and environmental factors are likely to be involved. Even if the pattern of inheritance of these conditions is unclear, having a family member with a colitis sore increases the risk of developing the disease [4].

\section{Prevalence of Colitis Ulcer Disease}

Colitis ulcers are more common in North America and Western Europe. However, the prevalence is increasing in other areas. In North America, colitis affects about 40 to 240 people per 100,000 people. It is estimated that more than 750,000 people in North America suffer from this disorder. Colitis ulcers are more common in whites and Jews of Eastern and Central European descent (Ashkenazi) than in people of other ethnicities [5].

\section{Crohn's Disease}

\section{Ulcerative Colitis}

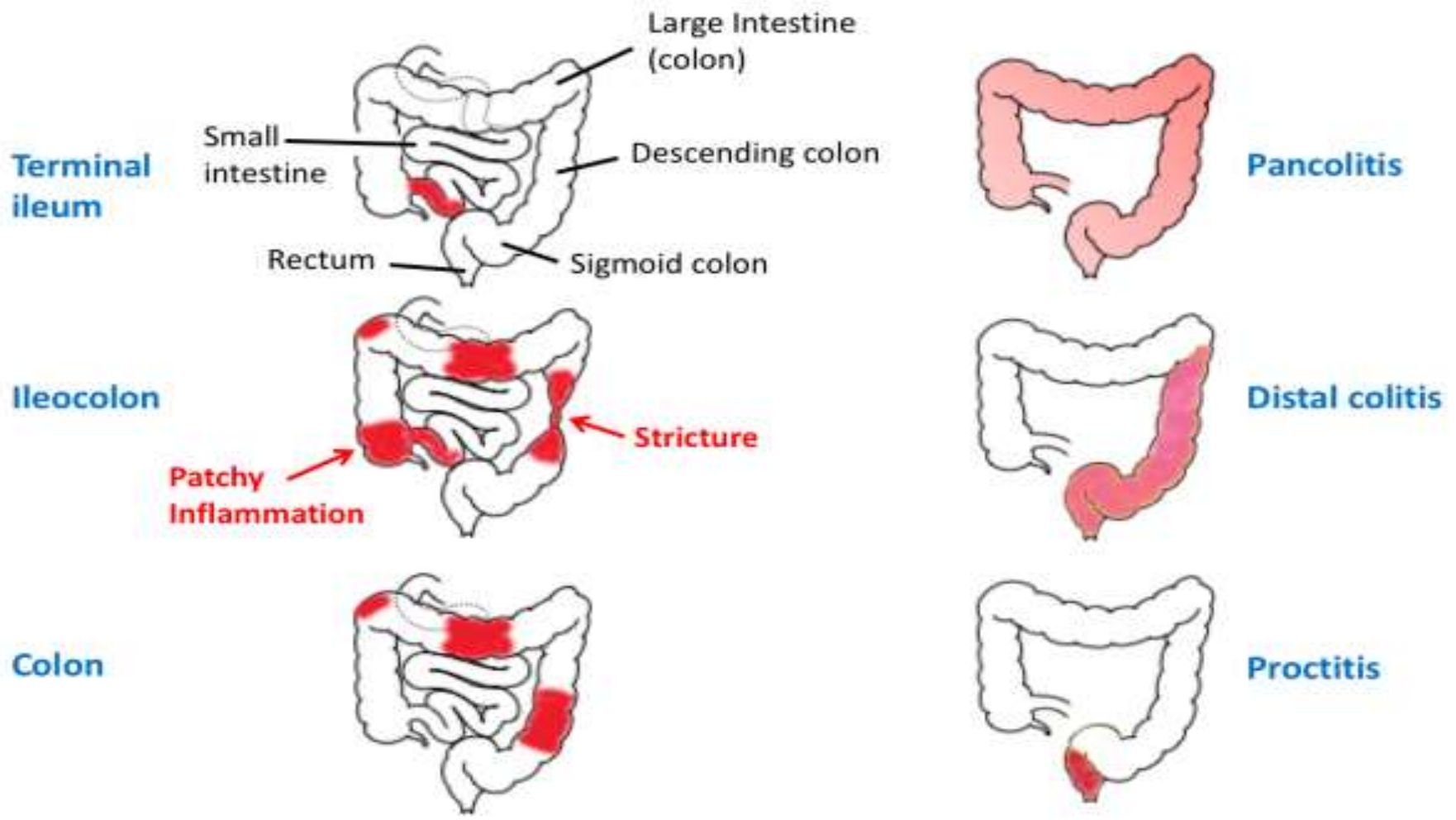




\section{Diagnosis of Colitis Ulcer Disease}

Colitis ulcers can be diagnosed based on the clinical findings of some patients and some pathological tests, and radiological imaging techniques. The most accurate method of diagnosing this disorder is radiation imaging with endoscopic technique [5].

\section{Treatment options for Colitis Ulcers}

The treatment and management strategy of colitis ulcer is symptomatic and supportive. Treatment may be done with the help and coordination of a team of specialists, including oncologists, gastroenterologists, surgeons, and other health care professionals. There is no effective treatment for this disease and surgery to remove colitis ulcers is not permanent. Genetic counseling is also important for all parents who want a healthy child [6, 7].

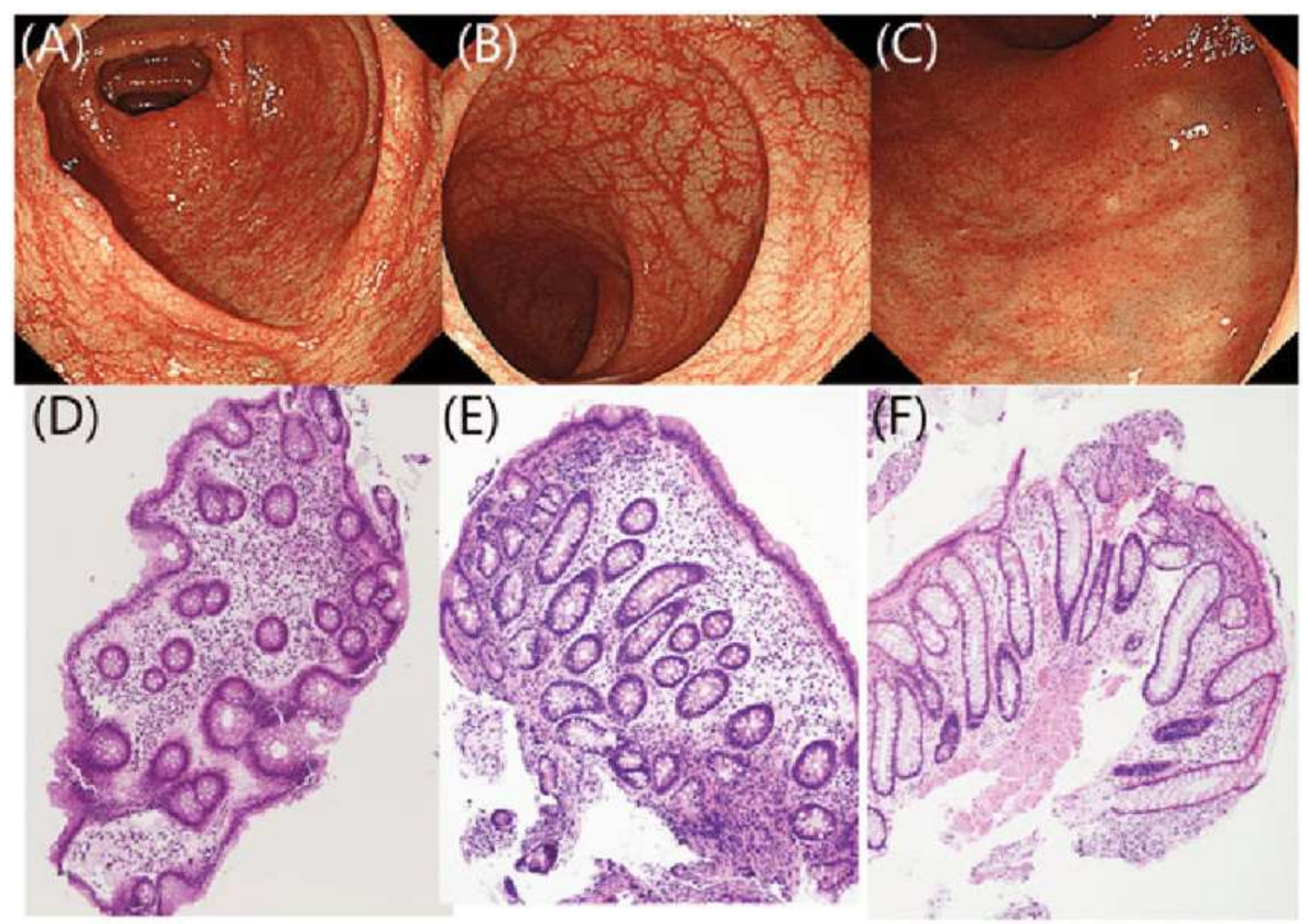

Figure 8: Endoscopic and microscopic images of colon tissue with colitis ulcer [6, 7].

\section{Discussion and Conclusion}

Researchers have found many genetic changes that are involved in ulcerative colitis but still do not know how these changes cause the disease. However, there are several theories:

Some of the genes associated with the disease are linked to the body's ability to produce proteins that form a protective barrier in the lining of the gut. This protective barrier keeps natural bacteria in the gut and any other toxins in the gut. If this protective barrier breaks, bacteria and toxins come in contact with the epithelial surface of the large intestine, which stimulates the immune system to react [8].

Other genes associated with ulcerative colitis affect $\mathrm{T}$ cells. T cells help identify bacteria and other foreign invaders in the body and attack them in the immune system [8].

Some genetic makeup may cause T cells to mistakenly attack bacteria that normally live harmlessly in the gut, or they may overreact to toxins or foreign invaders that have entered the large intestine. Show. This severe immune reaction causes ulcerative colitis. A 2012 study found that more than 70 genes could play a role in inflammatory bowel disease. Many of these genes have previously been linked to other immune disorders, such as psoriasis and ankylosing spondylitis [9].
It is true that genetics play an important role in this disease, but remember this is only part of the puzzle. Most people with ulcerative colitis have no family history [9].

In general, inflammatory bowel disease is more common in developed countries, especially in urban areas. Air pollution, diet and chemicals may play a role in increasing the risk of this disease [9].

Possible stimuli associated with ulcerative colitis include:

Lack of exposure to bacteria and germs in childhood, which prevents the immune system from developing normally [9].

A diet high in sugar and red meat and low in omega-3 fatty acids and vegetables

Vitamin D deficiency

Exposure to antibiotics in childhood

Taking aspirin and other non-steroidal anti-inflammatory drugs

Infection with bacteria or viruses such as Salmonella, E. coli and measles

\section{References}

1. Anderson CA, Boucher G, Lees CW, Franke A, D'Amato M, Taylor KD (2011). Meta-analysis identifies 29 additional 
ulcerative colitis risk loci, increasing the number of confirmed associations to 47. Nat Genet. 2011 Mar; 43(3):246-52. doi: 10.1038/ng.764. Epub 2011 Feb 6. Erratum in: Nat Genet. 43(9):919.

2. Danese S, Fiocchi C. (2011). Ulcerative colitis. N Engl J Med. Nov 3; 365(18):1713-25. doi: 10.1056/NEJMra1102942. Review.

3. Di Sabatino A, Biancheri P, Rovedatti L, Macdonald TT, Corazza GR. (2011). Recent advances in understanding ulcerative colitis. Intern Emerg Med. 2012 Apr;7(2):103-11. doi: 10.1007/s11739011-0719-z. Epub Review.

4. McGuckin MA, Eri R, Simms LA, Florin TH, Radford-Smith G. (2009). Intestinal barrier dysfunction in inflammatory bowel diseases. Inflamm Bowel Dis. Jan;15(1):100-13. doi: 10.1002/ibd.20539. Review.

5. Pigneur B, Escher J, Elawad M, Lima R, Buderus S (2013). Phenotypic characterization of very early-onset IBD due to mutations in the IL10, IL10 receptor alpha or beta gene: a survey of the Genius Working Group. Inflamm Bowel Dis.; 19(13):28208. doi: 10.1097/01.MIB.0000435439.22484.d3.

6. Podolsky DK. (2002). Inflammatory bowel disease. N Engl J Med. Aug 8;347(6):417-29. Review.

7. Shim JO, Seo JK. (2014). Very early-onset inflammatory bowel disease (IBD) in infancy is a different disease entity from adultonset IBD; one form of interleukin-10 receptor mutations. J Hum Genet. Jun;59(6):337-41. doi: 10.1038/jhg.2014.32. Epub 2014 May 1.

8. UK IBD Genetics Consortium, Barrett JC, Lee JC, Lees CW, Prescott NJ. (2009). Genome-wide association study of ulcerative colitis identifies three new susceptibility loci, including the HNF4A region. Nat Genet.; 41(12):1330-4. doi: 10.1038/ng.483. Epub 2009 Nov 15.

9. Xavier RJ, Podolsky DK. (2011). Unravelling the pathogenesis of inflammatory bowel disease. Nature. 2007 Jul 26; 448(7152):42734. Review.
This work is licensed under Creative Commons Attribution 4.0 License

To Submit Your Article Click Here: Submit Manuscript

DOI: $10.31579 / 2641-5194 / 051$

\author{
Ready to submit your research? Choose Auctores and benefit from: \\ $>$ fast, convenient online submission \\ $>$ rigorous peer review by experienced research in your field \\ $>$ rapid publication on acceptance \\ $>$ authors retain copyrights \\ $>$ unique DOI for all articles \\ $>$ immediate, unrestricted online access
}

At Auctores, research is always in progress.

Learn more https://www.auctoresonline.org/journals/gastroenterologypancreatology-and-hepatobilary-disorders 